\title{
Reuse of Iraqi Agricultural Drainage Water Using Nanofiltration
}

\author{
Mohammad F. Abid“, Saadi K. Al-Naseri and Samirra N. Abdullah \\ ${ }^{a}$ Chemical Engineering Department-University of Technology, P.O. 35010, Baghdad, Iraq \\ ${ }^{b}$ Ministry of Science and Technology, Baghdad, Iraq
}

\begin{abstract}
Irrigated areas between Euphrates and Tigris rivers in Iraq suffer from salinity buildup in the root zone of corps. Agricultural drain water (ADW) from these areas is collected in a single main drain canal, in an annual flow rate of about 6 billion cubic meter. In the present work, a pilot-scale nanofiltration membranes unit was used to evaluate the feasibility of desalinating ADW from the main drain canal for further reuse. Bench scale experiments were conducted to determine the optimum anti-scale dosage values in the unit. These values were verified in a plate type laboratory scale NF membrane to visually monitor the onset of crystal appearance behavior. A method for calcium sulfate precipitation control is presented and an empirical correlation of anti-scale dosage as a function of concentration factor (CF) was obtained. A pilot-scale unit was used to investigate the performance of NF membrane. High rejection values for both cations and anions indicate that the use of NF membrane in desalinating ADW from the Iraqi main drain canal is promising. The treated drainage water is considered good for irrigation when classified according to Wilcox classification.
\end{abstract}

Keyword: Agricultural water, Revers osmosis, Nanofiltration, Salinity, Antiscalant, Water reuse.

\section{INTRODUCTION}

Many agricultural parts of the word, especially in arid and semiarid regions, suffer from adverse effects of irrigation, such as water logging and soil salinity. Concurrently, fresh water resources continue to dwindle either from excessive use or from deterioration of water quality due to contamination [1]. The agricultural sector is the largest user, and consumer, of water in Iraq, with its share exceeding $75 \%$ of the total gross demand for water [2]. On a consumptive use basis (the water fraction that evapotranspires during use), the share of irrigation water is even higher at more than $80 \%$ [2]. Future increase in overall irrigation supply will depend on changes in the (priorities) demands for the municipal and industrial sectors, development of new groundwater resources and measures to reduce the outflow (terminal drainage) from the Euphrates-Tigris system.

Agricultural drainage water (ADW) is a complex mixture of dissolved and suspended organic and inorganic components as well as a wide variety of microorganisms [3]. The feasibility of membranes for drainage water reclamation was first demonstrated in 1971 at Firebaugh, California ([4, 5]). Since then, serious consideration has been given to membrane technology for reclamation and reuse of agricultural drainage water in the one of the largest agricultural centers of the word, the San Joaquin Valley, CA [6].

${ }^{*}$ Address correspondence to this author at the Chemical Engineering Department-University of Technology, P.O. 35010, Baghdad, Iraq;

Tel: +9647709229217; E-mail: jumaili_mfa@yahoo.com
Interruption of drainage has created a severe hardship for the farming community. If not resumed, a gradual salinity build-up will necessitate the retirement of large areas of fertile agricultural land. Consideration of water quality in relation to optimization of the desalination process is especially critical with agricultural drainage water. Authors, such as Le Gouellec and Elimelech [3], have studied experimentally the conditions for gypsum scale formation on nanofiltration (NF) membrane surfaces for the reclamation of ADW. They reported that scaling occurred at low water recoveries, and was mostly due to calcium sulfate (gypsum) formation of the membrane surface. Applications of water and wastewater treatments by nanofiltration membrane are not wellknown in Iraq [7]. In the present work, a laboratory and a pilot investigation was carried out to evaluate the feasibility of (NF) membrane desalination of agricultural drainage water in the Euphrates and Tigris rivers in Iraq. The treated water will be evaluated for its salts concentration and classified by applying Wilcox diagram [8] to judge its suitability for irrigation.

\subsection{Description of the Field}

In Iraq, the construction of the main drain canal (MDC) began in 1953 to drain saline water used for irrigation and was completed in 1993, and its functions are as follows:

1. To receive water drained from irrigated areas between Euphrates and Tigris Rivers which will lead to decrease soil salinity and increase land productivity. 


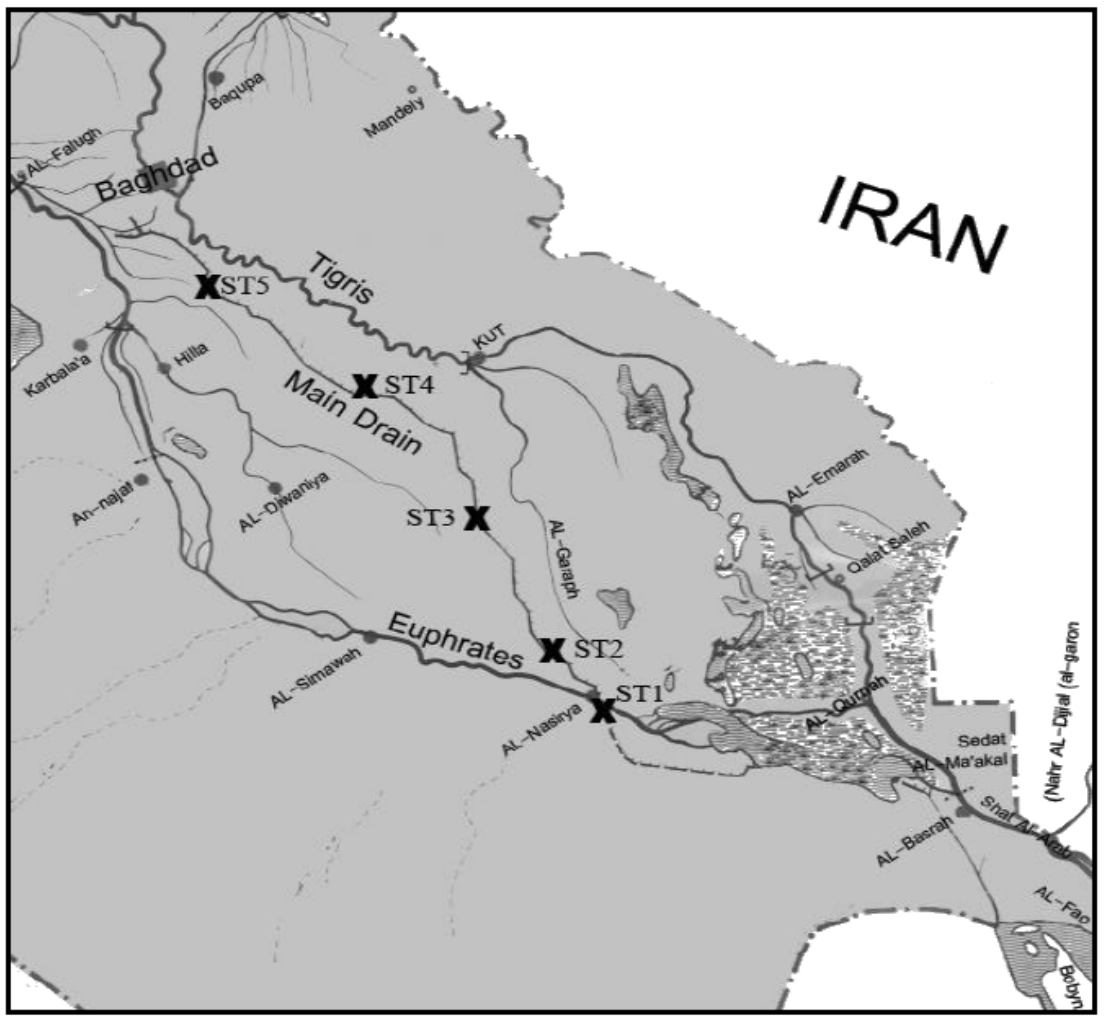

Figure 1: Map showing south part of Iraq and the Main Drain Canal pathway together with Tigris and Euphrates rivers.

2. To protect Euphrates and Tigris Rivers from pollution due to discharges from irrigated areas.

3. To act as a barrier or border against expansion of sand dunes towards the irrigated areas.

Figure 1 illustrates the main drain canal (MDC) which originates from Ishaqi Canal, $65 \mathrm{~km}$ to the north of Baghdad, and ends at a confluence with the Basra Canal $500 \mathrm{~km}$ to the south of Baghdad. The MDC is divided into three sectors; namely, the northern sector (206 km), the middle sector $(187 \mathrm{Km})$, and the southern sector $(172 \mathrm{~km})$. There are five monitoring stations (ST1 to ST-5) for water quality along the MDC as shown in Figure 1. The MDC collects water from the subchannels and main drains along its course, and sum an annual quantity of about 6 billion cubic meters. These different sources contain several types of pollutants that affect the water quality and conditions of the surrounding environment. Water may contain organic chemicals, organic matters, dissolved salts, pesticides, herbicides, manure, and fertilizers.

\section{MATERIAL AND MATERIALS}

\subsection{Sample Collection and Analysis}

Water quality monitoring program was conducted at three locations along the MDC (ST2, ST3, and ST5) for three months (May, August and October, 2011). The total number of collected samples is 45 , and were collected at a depth of $30 \mathrm{~cm}$ below water surface (15 samples per month with 5 samples per location) starting from ST2 downstream the MDC up to ST5. The samples were collected by using Van Dorn water sampler, and were immediately filtered through a 0.45 $\mu \mathrm{m}$ Millipore filter paper. The filtrated samples were placed in plastic containers ( 1 liter) and frozen until the time of analysis in the central laboratories-Baghdad. Standard methods procedures were followed for the desirable test methods for the monitored parameters [9]. Sampling results are shown in Table 1 together with surface water values for Euphrates River $80 \mathrm{~km}$ to the south of Baghdad. In membrane experiments, synthesized agricultural drainage water was prepared and stored in the feed water tank.

\subsection{Experimental Procedure and Apparatus}

\subsubsection{Jar Tests}

To determine the required antiscalant dosage, bench-scale jar tests were conducted for different concentration factors (CF) of the actual ADW based on the analysis at ST3-location. The tested antiscalant is Hypersperse AS20, which is widely used and commercially available in Iraqi local market. 
Table 1: Properties of the Agricultural Drain Water at 3 Monitoring Stations

\begin{tabular}{|c|c|c|c|c|c|}
\hline Property & Unit & ST2 & ST3 & ST5 & Euphrates River \\
\hline Electric conductivity (EC) & $\mu S / \mathrm{cm}$ & 8400 & 5900 & 3800 & 1400 \\
\hline $\mathrm{pH}$ & & 8.2 & 8.2 & 8.3 & 8.1 \\
\hline Hardness, as $\mathrm{CaCO}_{3}$ & $\mathrm{mg} / \mathrm{l}$ & 7132 & 4698 & 3733 & 1066 \\
\hline TOC & $\mathrm{mg} / \mathrm{l}$ & 1.41 & 1.13 & 0.72 & 0.12 \\
\hline Calcium $\left(\mathrm{Ca}^{++}\right)$ & $\mathrm{mg} / \mathrm{l}$ & 432 & 284 & 188 & 106 \\
\hline Magnesium $\left(\mathrm{Mg}^{++}\right)$ & $\mathrm{mg} / \mathrm{l}$ & 520 & 380 & 305 & 78 \\
\hline Sodium $\left(\mathrm{Na}^{+}\right)$ & $\mathrm{mg} / \mathrm{l}$ & 733 & 531 & 377 & 119.6 \\
\hline Potassium $\left(\mathrm{K}^{+}\right)$ & $\mathrm{mg} / \mathrm{l}$ & 5.46 & 4.68 & 4.29 & 2.34 \\
\hline Chloride $\left(\mathrm{Cl}^{-}\right)$ & $\mathrm{mg} / \mathrm{l}$ & 1352 & 1051 & 657 & 234 \\
\hline Sulphate $\left(\mathrm{SO}^{*}\right)$ & $\mathrm{mg} / \mathrm{l}$ & 2621 & 1690 & 1377 & 350 \\
\hline Bicarbonate ( $\left.\mathrm{HCO}^{-}\right)$ & $\mathrm{mg} / \mathrm{l}$ & 213.5 & 201 & 183 & 158.6 \\
\hline Sodium Percent & $\%$ & $44 \%$ & $44 \%$ & $44 \%$ & $40 \%$ \\
\hline
\end{tabular}

Jar tests were conducted in $500 \mathrm{ml}$ beakers with magnetic stirrers (see Figure 2). The temperature was maintained at $25^{\circ} \mathrm{C}$ by using a controlled temperature heater. A 9320BN Calcium Half-Cell Electrode from Thermo Scientific was used to record data of the experiments.

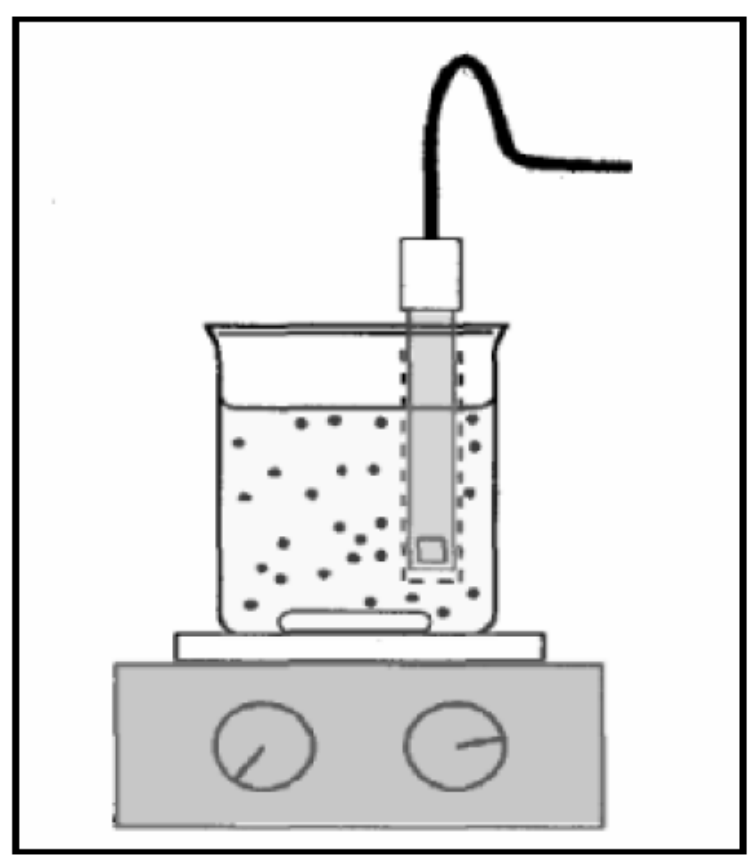

Figure 2: Apparatus of Jar test experiments.

A batch of four simultaneous tests could be run simultaneously. Each beaker was filled with a freshly synthesized ADW and a certain dosage of antiscalant. They were kept mixed and observed over a period of $24 \mathrm{~h}$. If the solution became slightly turbid then onset of precipitation was expected to occur.

\subsubsection{Bench-Scale Flat Sheet Membrane Experiments}

Bench-scale flat sheet membrane experiments were conducted to investigate visually the Onset of crystal appearance on the membrane at a specific flux of solution with different CFs. The bench scale unit (see Figure 3) consists of a pump (Procon 103A070F31, 1/3 hp; Dayton model 2R958) and a plate-and-frame NF membrane of dimensions $(7$ by $3 \mathrm{~cm}$ ) and a channel height of $4 \mathrm{~mm}$ were used. The fouled membrane surfaces were scanned with SEM (Type VEGA/Easy Probe from TESCAN) to visually inspects the crystal formation on the membrane. The ratio of onset precipitation CF on Jar test to onset crystal formation on membrane CF is directly related to the concentration polarization model (i.e., the ratio of membrane surface salt concentration to the bulk salt concentration) at specific flux [6].

\subsubsection{Pilot Scale Unit Study}

A pilot-scale nanofiltration membranes unit was used to evaluate the feasibility of desalinating ADW from the main drain canal for further reuse. This unit ws installed in the laboratories of the University of Technology in Baghdad. The testing unit is arranged as shown schematically in Figure 4. The unit consists of one low pressure pump, two micron filters (5 and 1 micron), one high pressure pump and a stainless steel membrane vessel of size 4 inch by 1.0 meter. The membrane vessel was equipped with a NF membrane type Hydraunatics ESNA1-4040. The unit is equipped with several flow meters, pressure gauges and electric 


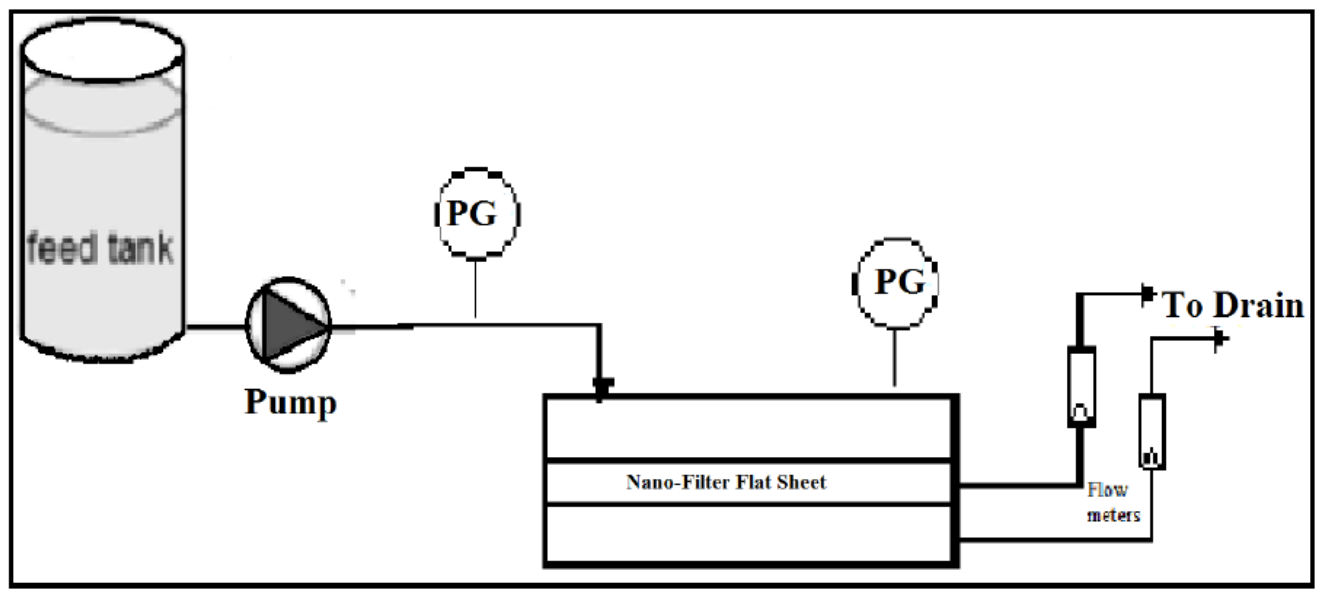

Figure 3: Schematic of continuous-flow NF flat-sheet test cell.

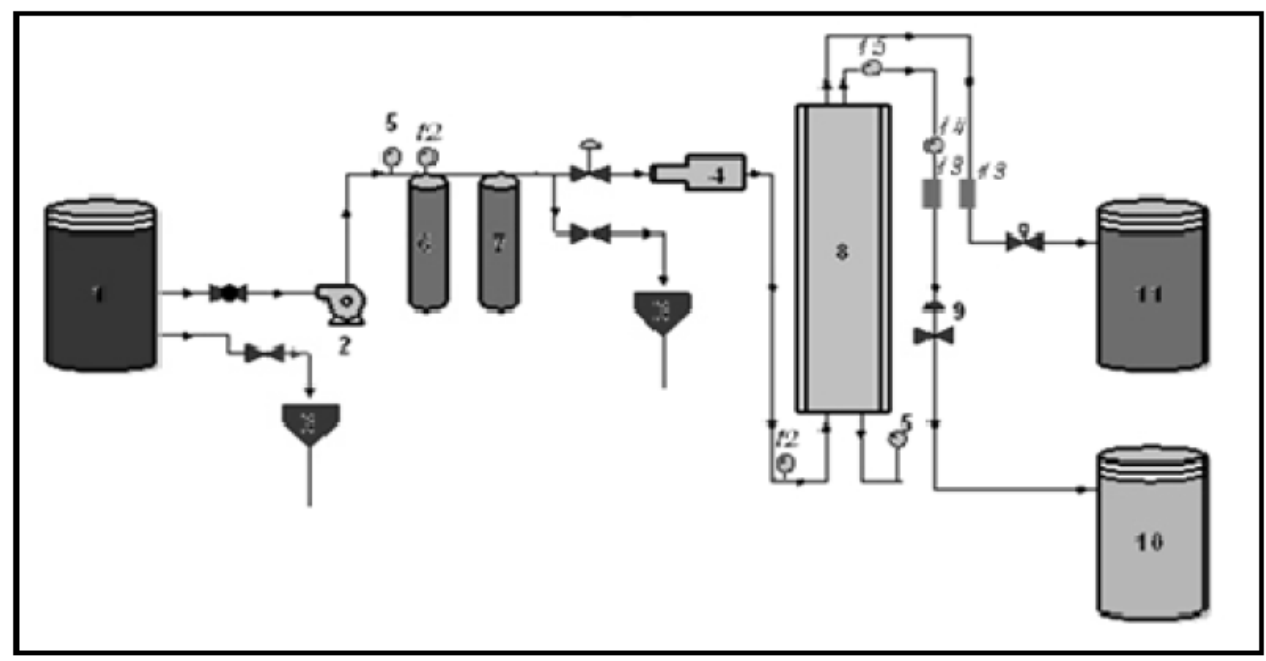

Figure 4: schematic diagram of the pilot unit: (1. Feed Water Tank, 2. Feed Water pump, 3. Drain, 4. High Pressure Pump, 5. Pressure Gauges, 6,7-MicronFilter $(5 \mu, 1 \mu)$, 8. Pressure vessel for membrane, 9. Regulating valve, 10. Permeate Tank, 11. Concentrate Tank).

conductivity meters that facilitate evaluating the various operating parameters.

The pilot unit contains three holding tanks, all made of polyethylene; the feed water tank (500 liter), the concentrate tank (500 liter) and the permeated water tank (125 liter). The permeated water can be recycled to the suction of the low pressure pump for further treatment and to increase the unit recovery. During operation, scale inhibitor (type Hypersperse AS20) was injected into the feed water at a rate determined by a bench-scale experiment described later. Acid was also injected to adjust the feed water $\mathrm{pH}$ to 6.8 in order to further reduce the potential calcium carbonate scaling. The unit was designed to handle up to $20 \mathrm{l} / \mathrm{min}$ feed water.

Test of NF membrane effectiveness was carried out at a fixed temperature of $25^{\circ} \mathrm{C}$ and a pressure of 8 bar.
Three feed solutions were used in the experiments. They were synthesized to simulate ADW concentrations of ions (see Table 1). MgSO4 was chosen as 1.04, 2.08, and $3.14 \mathrm{~g} / \mathrm{l}, \mathrm{CaCL} 2$ as 1.1, 2.2, and $3.3 \mathrm{~g} / \mathrm{l}$, and $\mathrm{NaCl}$ as $1.85,2.9$, and $5.8 \mathrm{~g} / \mathrm{l}$ in the three feed water types respectively. Prior to each experiment, the membrane was first washed using soft water for a period of 1-3 hrs, for the unit to reach steady-state flux condition.

\section{RESULTS AND DISCUSSION}

\subsection{Scale Formation and Concentration Polarization}

Figure 5 shows the effect of antiscalent on scaling of synthesized ADW that simulate the ST3 properties with a CF of 2.5 in the Jar tests. Precipitated calcium sulfate is indicated by a decrease in free calcium ion 


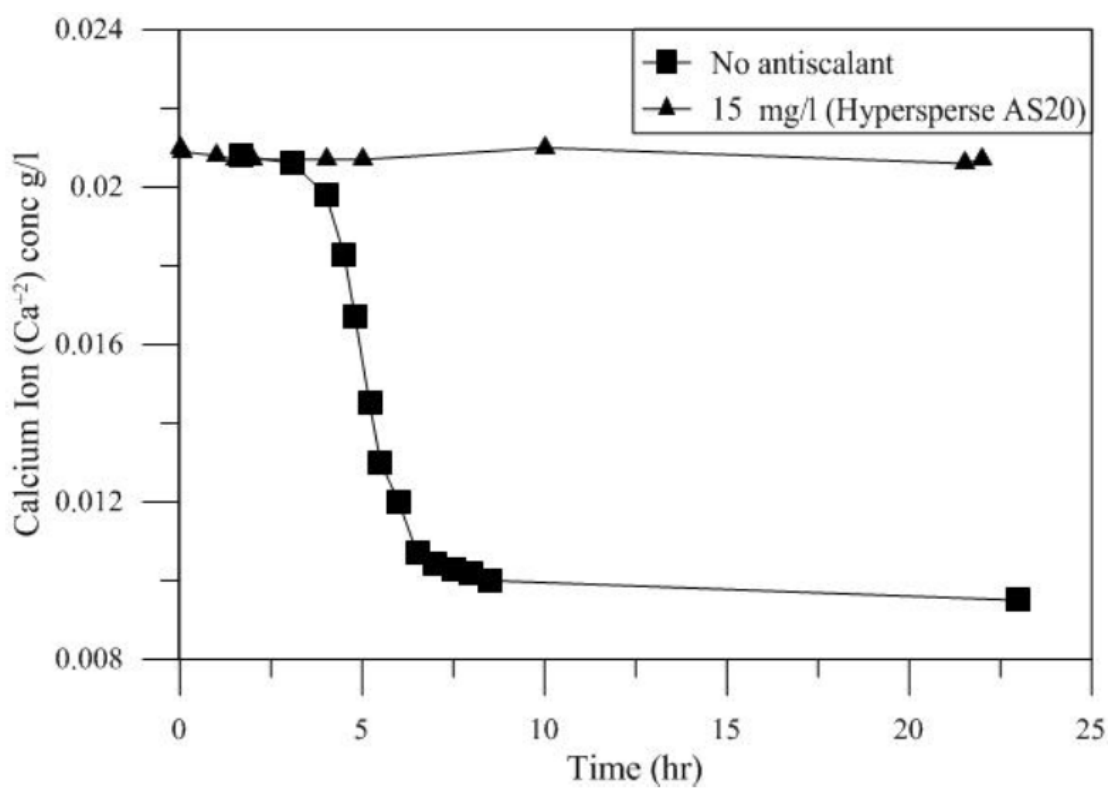

Figure 5: Effect of anti-scale dosage of $15 \mathrm{mg} / \mathrm{l}$ on ADW Calcium ion concentration at CF of 2.5.

concentration. When no antiscalent used, threshold of precipitation occurred after three hours. This time depends on the initial feed water concentration and temperature which control the formation of calcium nuclei. It may be proposed that the role of antiscalent is to inhibit the formation of calcium nuclei which accelerate calcium precipitation.

Figure 6 illustrates the effect of different concentration factors of synthesized ADW on the required dosage of the antiscalant used in the Jar tests at $\mathrm{pH}$ of 7.5 and temperature of $25^{\circ} \mathrm{C}$. Using regression analysis technique, an empirical correlation was found to fit the experimental data of Figure 6 , with $R^{2}=0.9877$.

$$
\text { Dosage }=a_{0}(C F)^{a_{1}}
$$

Where $\mathrm{a}_{0}=1.8703$ and $\mathrm{a}_{1}=0.8824$

This formula represents a guideline for utilizing the correct antiscalant dosage for every CF of wastewater.

Jar test experiments demonstrated that $6 \mathrm{mg} / \mathrm{l}$ of antiscalant was required to prevent calcium sulfate precipitation in feed water solution.

Figure 7 illustrates the time dependent-permeate flux data of a bench-scale flat-sheet membrane unit using CF 1.2 and CF 2.5 (7 and $15 \mathrm{mg} / \mathrm{l}$ antiscalant dosages) respectively of a synthesized ADW that

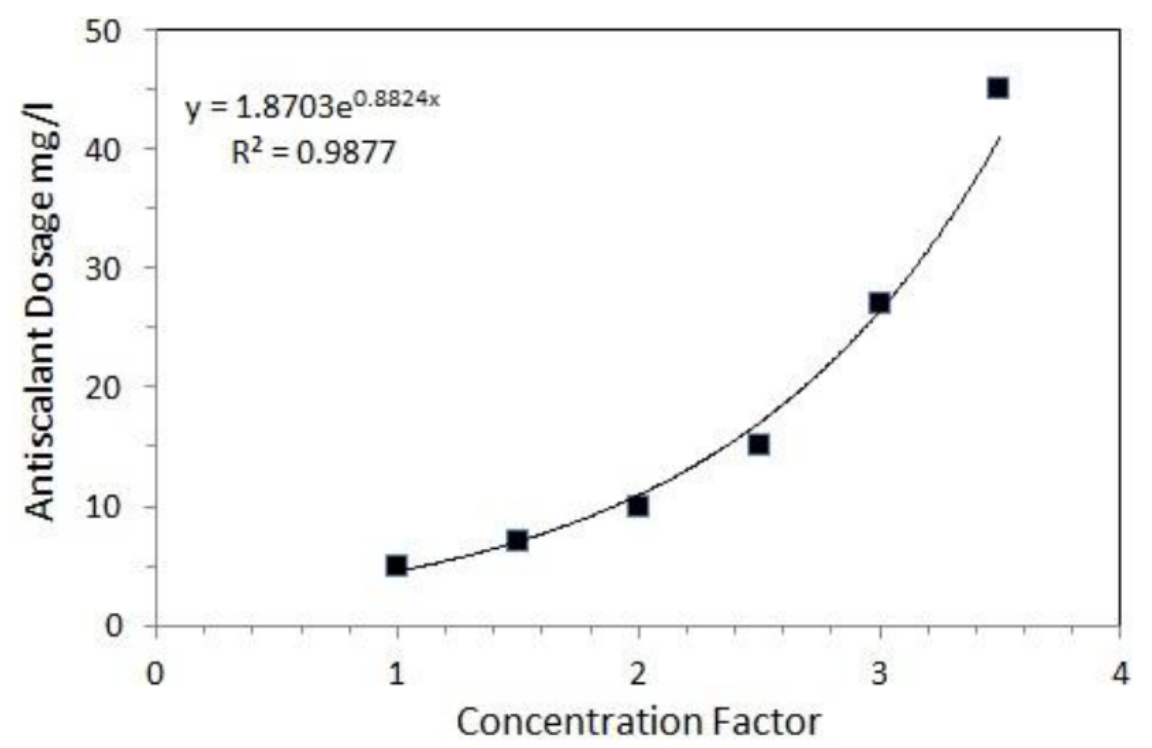

Figure 6: Hypersperse AS20 dosage required as a function of CFs to prevent precipitation (Jar tests). 


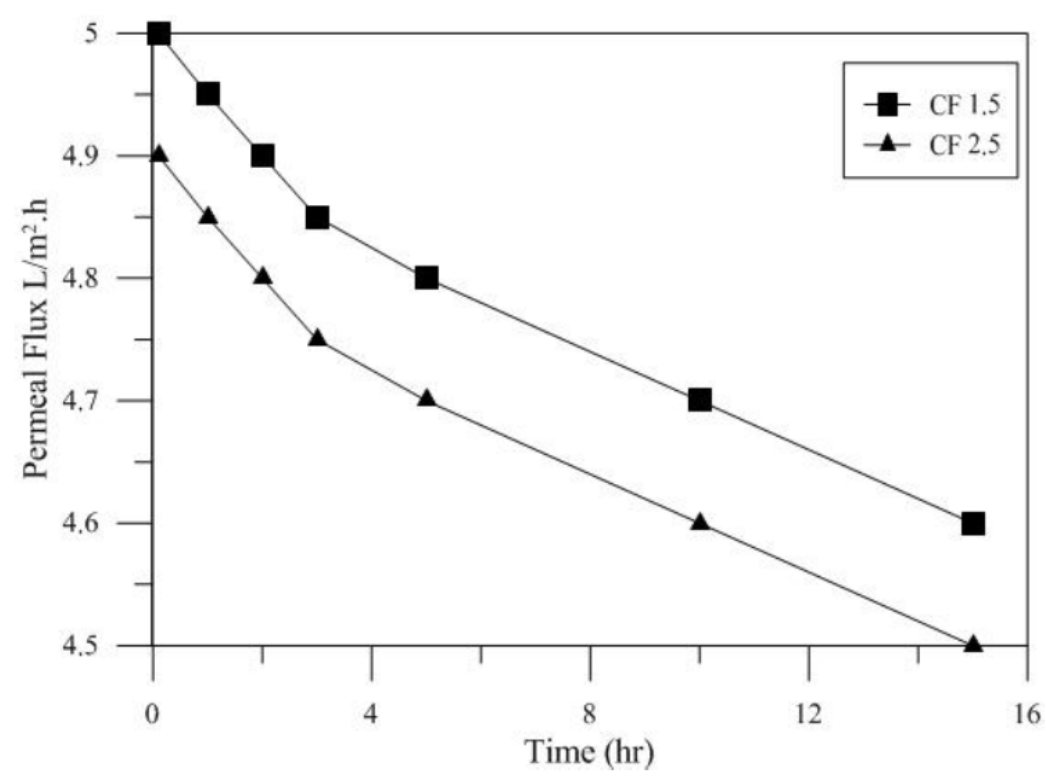

Figure 7: Effect of different $\mathrm{CFs}$ of synthesized $\mathrm{ADW}$ on permeate flux of $\mathrm{NF}$ unit (Feed $\mathrm{pH}=6$, temperature $=25^{\circ} \mathrm{C}$ ).
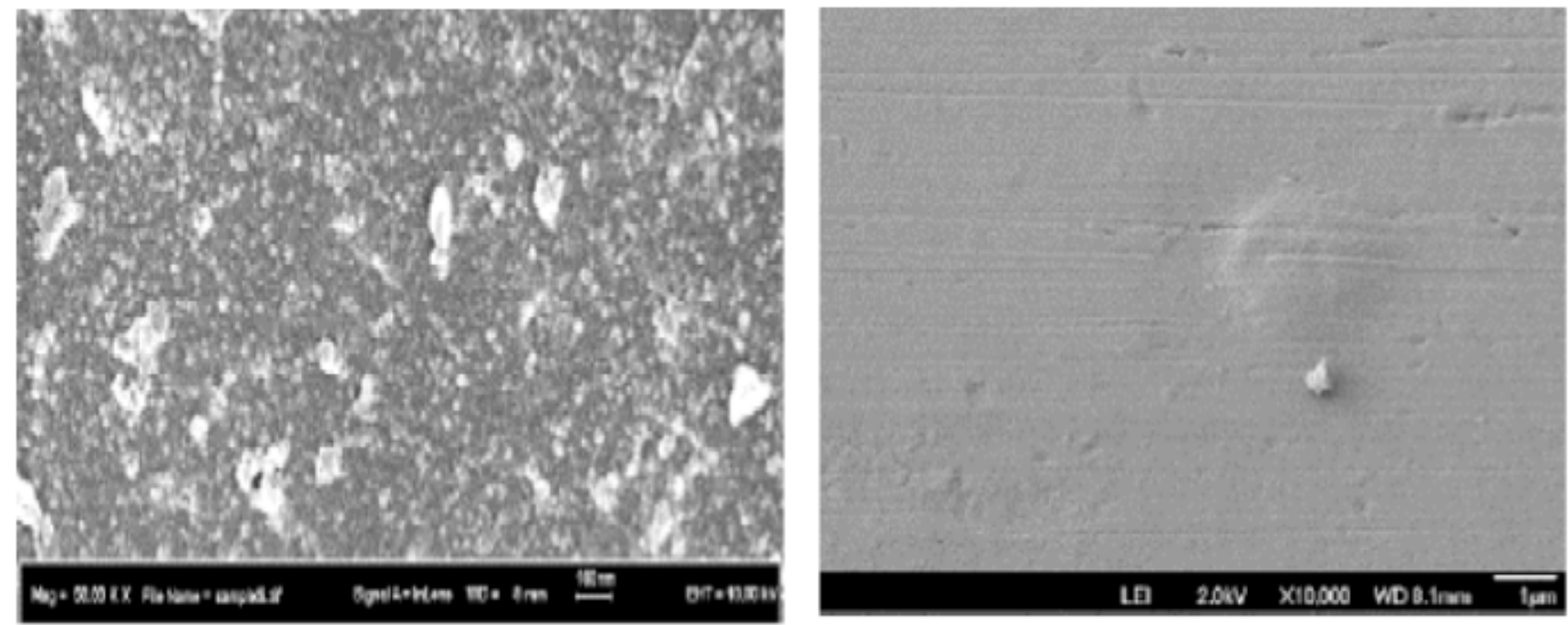

Figure 8: Effect of antiscalant on surface crystal morphology on Flat-sheet membrane. (Left) show early crystal formation, (Right) shows antiscalant effect.

simulated the properties of ST3. SEM images (Figure 8) demonstrated that the membrane surface is clear, which confirms the validity of the above equation.

\subsection{Pilot Unit Study}

\subsubsection{Permeate Flow}

The influences of feed water concentration on the volumetric flow rate of permeate water under steadystate conditions is illustrated in Figure 9. The figure shows that permeate flux for Magnesium sulphate and calcium chloride solutions was higher than that of $\mathrm{NaCl}$ solution, validating that the performance of the NF membrane is good for divalent ions. Since the comparison between $\mathrm{MgSO} 4, \mathrm{CaCl} 2$ and $\mathrm{NaCl}$ was done on an equivalent charge basis, the higher permeate flux for the calcium feed solution might be attributed to the lower number of calcium ions present in the feed.

\subsubsection{Salt Removal}

Removal results for different $\mathrm{MgSO}_{4}, \mathrm{CaCl}_{2}$ and $\mathrm{NaCl}$ concentrations are shown in Figure 10. As expected NF membrane demonstrate a higher salt removal for the solution of the divalent magnesium and calcium ions than for the univalent sodium ions. This behavior is in agreement with the findings of $[7,10,11]$ for multivalent electrolytes. Removal of Calcium and Sodium in the range of concentrations expected in the field (over the course of the drainage season) revealed 


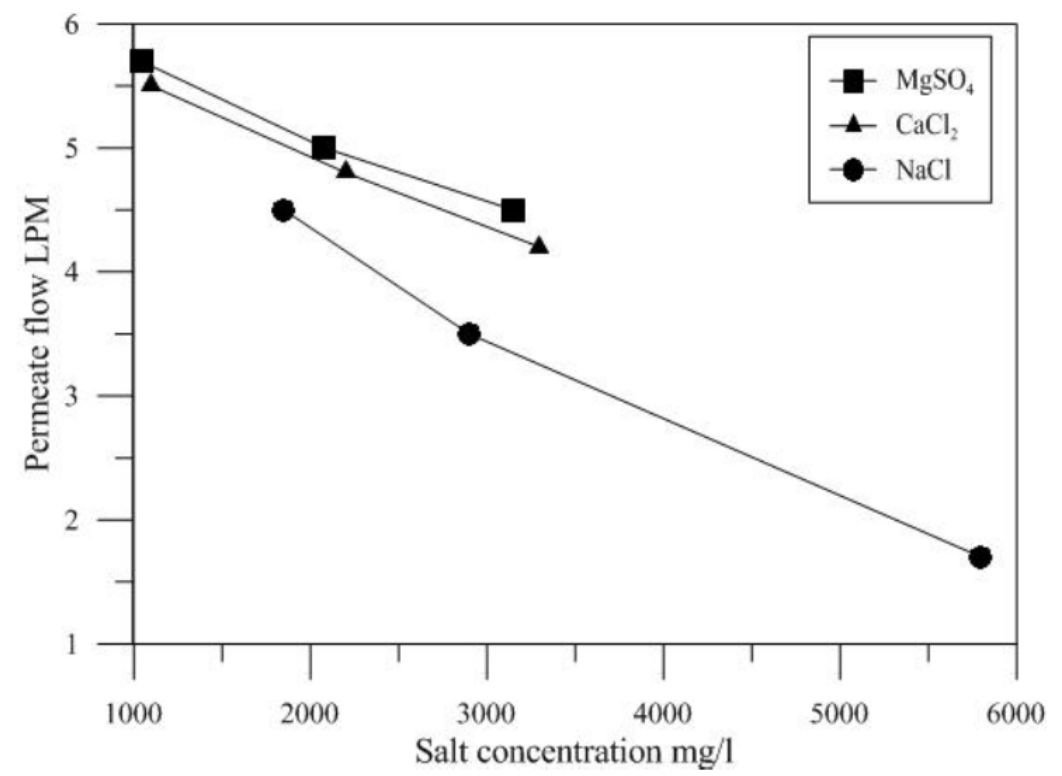

Figure 9: Relation between permeate flow rate for NF membrane unit at different feed water salt concentrations $(\mathrm{P}=7$ bar, $\mathrm{T}=$ $25^{\circ} \mathrm{C}, \mathrm{pH}=6.5$, Time of collection $=20 \mathrm{Hr}$ ).

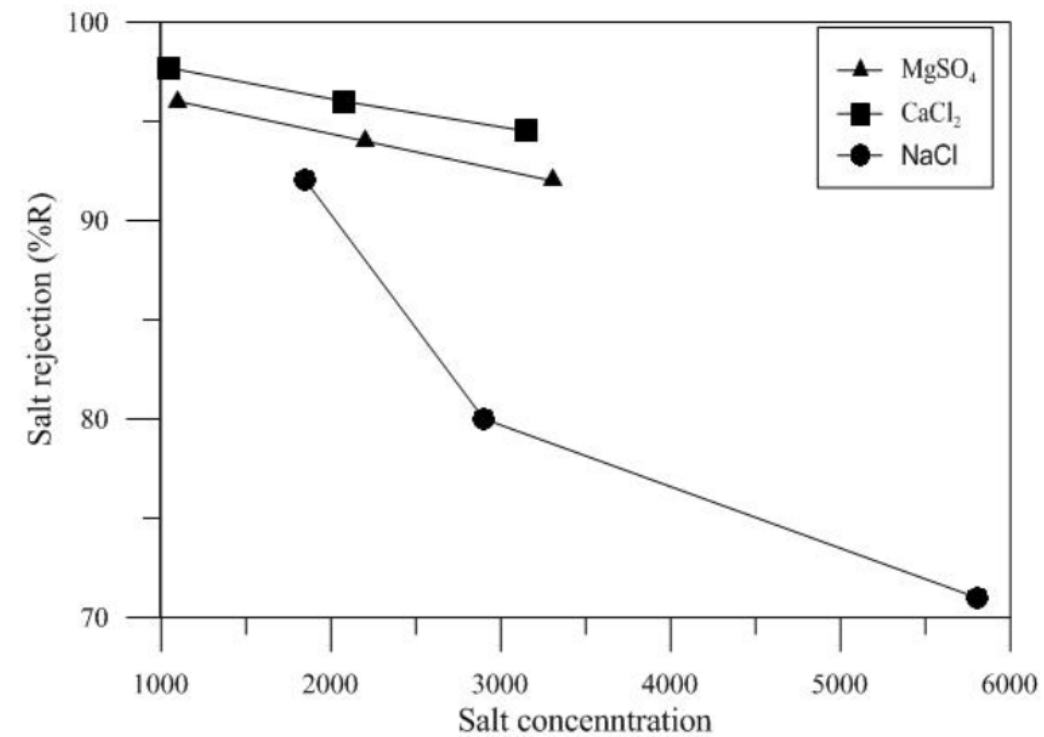

Figure 10: Effect of various salt concentrations on salt removal for $\mathrm{NF}$ membrane unit $\left(\mathrm{P}=7 \mathrm{bar}, \mathrm{T}=25^{\circ} \mathrm{C}, \mathrm{pH}=6.5, \mathrm{Time}\right.$ of collection $=20 \mathrm{Hr}$ ).

that higher feed concentrations caused a decrease in sodium removal but had less pronounced effect on calcium and magnesium rejection.

\subsubsection{Removal of lons}

Figures 11 and 12 depict the influence of the solute concentration on anion and cation removals in NF membrane respectively. In general, it can be observed that increasing the solute concentration decreased ion rejection. Both figures showed high removal values for both anions and cations. This indicates that the use of $\mathrm{NF}$ membrane in desalinating ADW from the Iraqi main drain canal is promising.
The theoretical removal sequence for the ions, based on the steric characteristics of ions (Table 2), should be as follows:

$$
\mathrm{Mg}^{2+}>\mathrm{Ca}^{2+}>\mathrm{SO}^{2-}>\mathrm{Na}^{+}>\mathrm{Cl}^{-}
$$

The experimental results showed the following sequence:

$$
\mathrm{SO}^{2-}>\mathrm{Mg}^{+}=\mathrm{Ca}^{+}>\mathrm{Na}^{+}>\mathrm{Cl}^{-}
$$

These results can be explained by the Donnan exclusion mechanism [12] and by the steric effect [13]. 


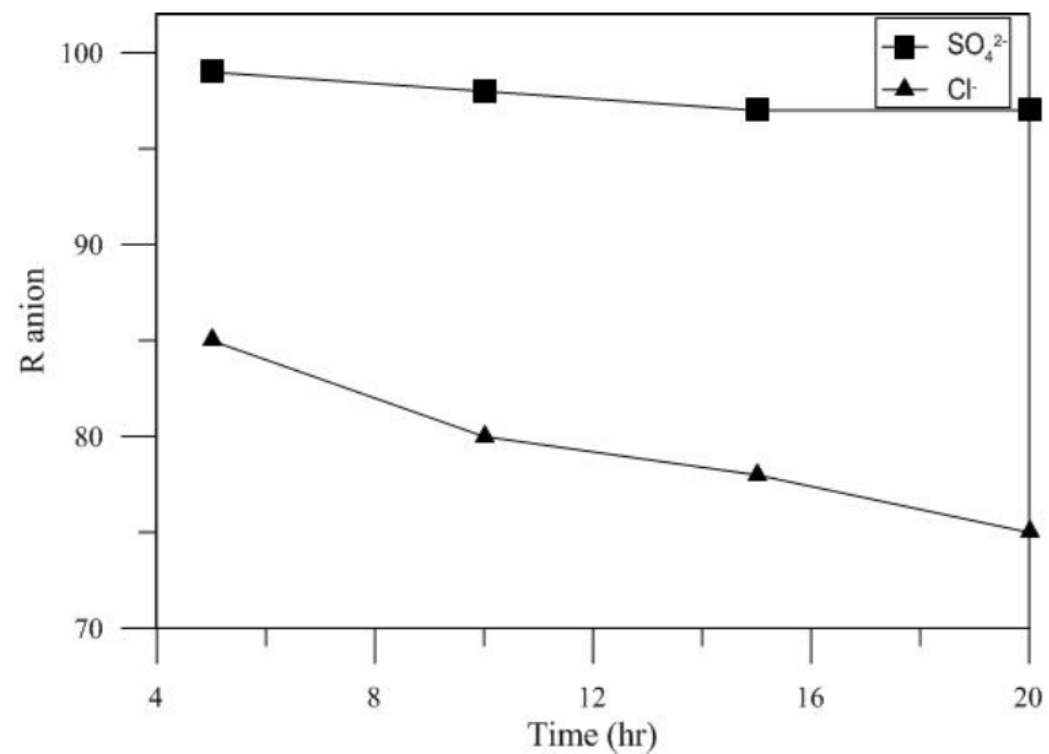

Figure 11: Variation of anion removal with operating time of $\mathrm{NF}$ membrane unit $\left(\mathrm{P}=7\right.$ bar, $\mathrm{T}=25^{\circ} \mathrm{C}, \mathrm{CF}=1.0$ at 6 ppm antiscalant).

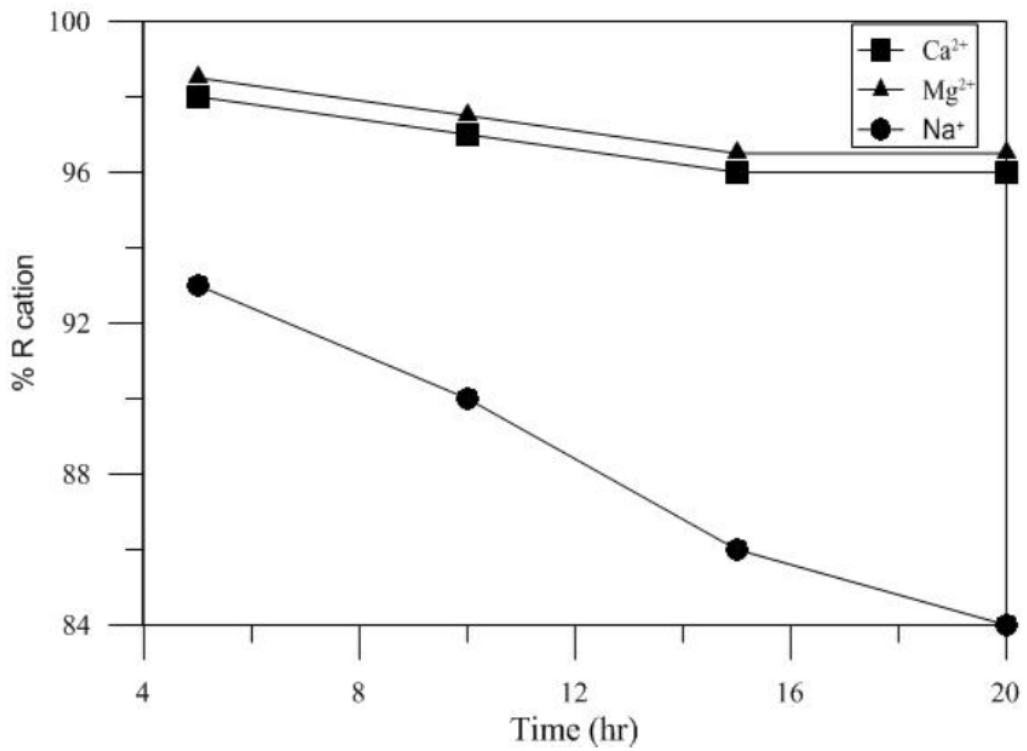

Figure 12: Variation of cation removal with operating time of $\mathrm{NF}$ membrane unit $\left(\mathrm{P}=7 \mathrm{bar}, \mathrm{T}=25^{\circ} \mathrm{C}, \mathrm{CF}=1.0\right.$ at $6 \mathrm{ppm}$ antiscalant).

Table 2: Steric Characteristics of lons [13]

\begin{tabular}{|c|c|c|c|}
\hline Ion & lonic radius, $\mathbf{n m}$ & Hydrated radius, $\mathbf{n m}$ & Hydration enthalpy, $\mathbf{k J} / \mathbf{m o l}$ \\
\hline \hline $\mathrm{SO}_{4}{ }^{2-}$ & 0.230 & 0.394 & -1138 \\
\hline $\mathrm{Ca}^{2+}$ & 0.099 & 0.412 & -1577 \\
\hline $\mathrm{Cl}^{-}$ & 0.18 & 0.332 & -376 \\
\hline $\mathrm{Mg}^{2+}$ & 0.065 & 0.428 & -1931 \\
\hline $\mathrm{Na}^{+}$ & 0.095 & 0.358 & -407 \\
\hline
\end{tabular}

Finally, in order to evaluate the suitability of the produced water for irrigation, the Wilcox classification diagram has been used (see Figure 13) [8]. In this diagram the adverse effect of sodium concentration is 


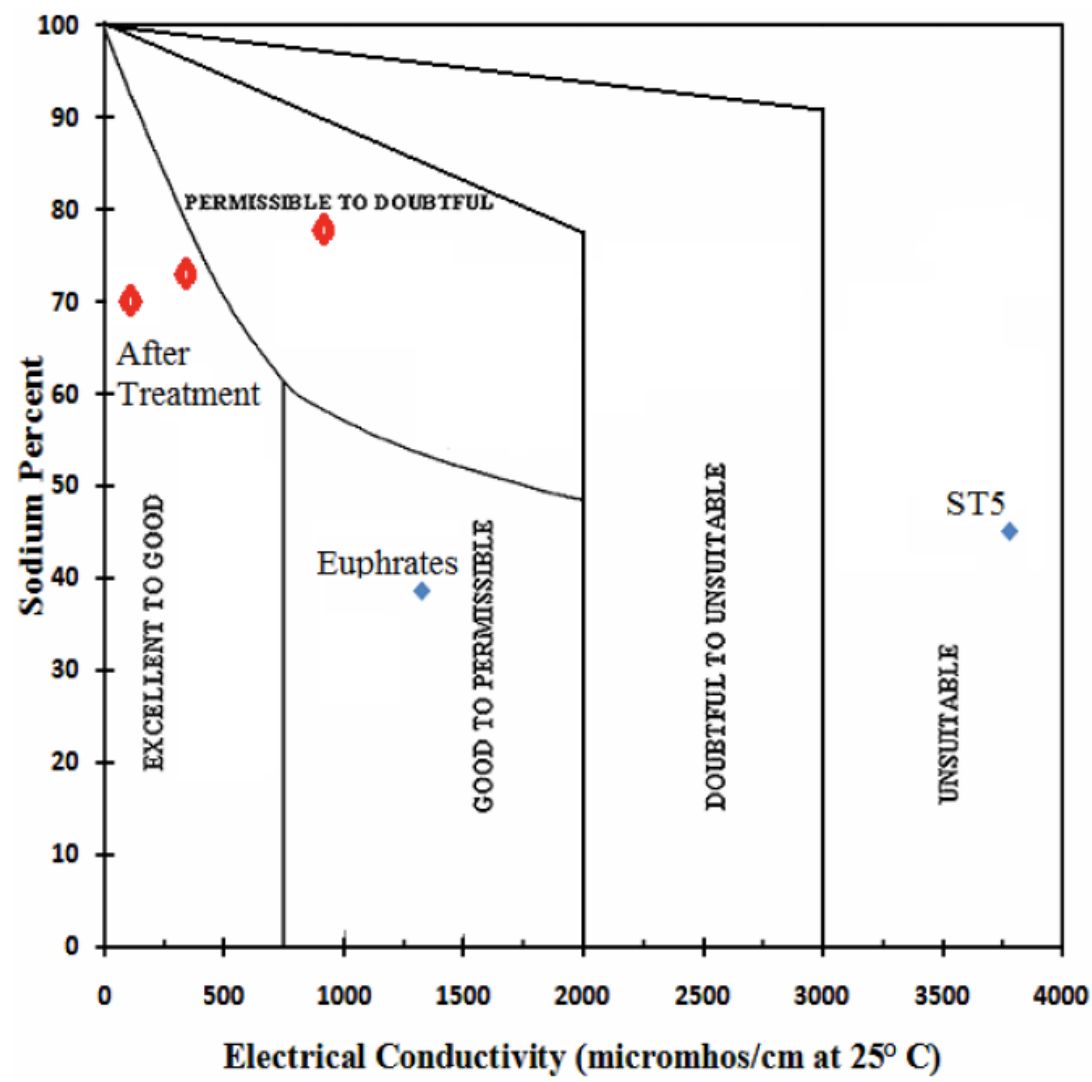

Figure 13: Wilcox diagram for sodium percentage and electrical conductivity for classification of irrigation water.

considered. From this figure, it is clear that the raw drainage water at ST5 (which has the lowest salt concentration) is considered unsuitable. Euphrates water at the same location is considered good to permissible. After treatment, two of the three drainage water sources (ST5, ST4) were changed into excellent to good for irrigation, and the third source (from ST3) was changed into permissible to doubtful.

\section{CONCLUSIONS}

Bench and pilot-scale investigations were carried out to evaluate the feasibility of NF membrane desalination of Iraqi agricultural drainage water. The final conclusions of this work are:

1. Jar test experiments and continuous-flow NF flatsheet test showed that a $6 \mathrm{ppm}$ antiscalant is enough to avoid calcium crystal precipitation on NF membrane for desalination of drainage water.

2. An empirical correlation based on power-low expression was developed to describe the relation between the required dosage of antiscalant and the concentration of the drainage water with a coefficient of determination $R^{2}=0.998$.
3. Results indicated that salt removal was found to be decreased with increasing salt concentration, and rejection of magnesium, calcium and sodium over the range of concentrations expected in the field (over the course of the drainage season) revealed that higher feed concentrations causes a decrease in sodium rejection but had a less pronounced effect on magnesium and calcium rejection. High rejection values for both cations and anions indicate that the use of NF membrane in desalinating ADW from the Iraqi main drain canal is promising.

4. The treated water from the drainage water is considered good for irrigation, when Wilcox classification was applied.

\section{REFERENCES}

[1] Sorour MH, Abulnour AG, Talaat HA. Desalination of agricaltural drainage water. Desalination 1992; 86: 63-75. http://dx.doi.org/10.1016/0011-9164(92)80024-4

[2] Behnam S. Conference on Water management and pollution control in Iraq. Amman: s.n., 2001.

[3] Le Gouellec YA, Elimelech M. Calcium sulfate (gypsum) scaling in nanofiltration of agricultural drainage water. $J$ Membr Sci 2002; 205: 279. http://dx.doi.org/10.1016/S0376-7388(02)00128-X 
[4] McCutchan WJ. Saline water research UCLA-ENG-7201. s.I.: Water resources desalination 1972; Report No. 47.

[5] McCutchan WJ. Saline water progress report. s.I.: University of california 1975; 62: 25-34.

[6] Ron WL, Julius G, Yoram C, Chris M, Kurt K. Low-pressure $\mathrm{RO}$ membrane desalination of agricultural drainage water. Desalination 2003; 155: 109-20. http://dx.doi.org/10.1016/S0011-9164(03)00288-1

[7] Abid MF, Al-Nasri SK, Al-Salhi QA, et al. Desalination of Iraqi surface water using nanofiltration membrane. Desalination Water Treatment 2011; 29: 174-80. http://dx.doi.org/10.5004/dwt.2011.1845

[8] Wilcox LV. The quality of water for irrigation use. US Department of Agriculture Technology Bulletin 1948; 49: 962.

[9] APHA, AWWA, WEF. Standard Methods for the Examination of Water and Wastewater, 21st edition. Washington, D.C.: s.n., 1999.
[10] Hanra AM, Ramachandhran V. RO performance analysis of cellulose acetate and TFC polyamide membrane systems for separation of trace contaminants. Desalination 1996; 104: 175.

http://dx.doi.org/10.1016/0011-9164(96)00040-9

[11] Ismail AF, Lau WJ. Influence of feed conditions on the rejection of salt and dye in aqueous solution by different characteristics of hollow fiber nanofiltration membranes. Desalination and Water Treatment 2009; 6: 281-88. http://dx.doi.org/10.5004/dwt.2009.479

[12] Rautenbach R, Groschl A. Separation potential of nanofiltration membranes. Desalination 1990; 77: 73.

[13] Marcus Y. Ion salvation. New York: Wiley 1985.

Received on 10-11-2012

Accepted on 28-01-2013

Published on 28-02-2013

\section{DOI: http://dx.doi.org/10.6000/1929-6037.2013.02.01.6}

(C) 2013 Abid et al.; Licensee Lifescience Global.

This is an open access article licensed under the terms of the Creative Commons Attribution Non-Commercial License (http://creativecommons.org/licenses/by-nc/3.0/) which permits unrestricted, non-commercial use, distribution and reproduction in any medium, provided the work is properly cited. 